\title{
MiK Piechotka author partnership
}

\section{Michał Piechotka, Maciej Piechotka}

Maria Kazimiera Piechotka née Huber was born on $12^{\text {th }}$ July 1920 in Cracow, died on $28^{\text {th }}$ November 2020 in Warsaw. She spent her childhood and youth in Tarnów. She attended Ursuline Sisters school. She was a scout. She passed her secondary school final exams in 1938 and the same year began her studies at the Faculty of Architecture at the Warsaw University of Technology. During the war, she worked as a building technician and in 1942 she started to study at the Secret Faculty of Architecture in Warsaw. She participated in the Warsaw Uprising. During the uprising she married Kazimierz Maciej Piechotka. She was a prisoner of war in Zeithain POW camp. After returning to Poland in May 1945 she took up a job at the Polish Studio for the Conservation of Cultural Property and continued her studies at the same time. She graduated from the

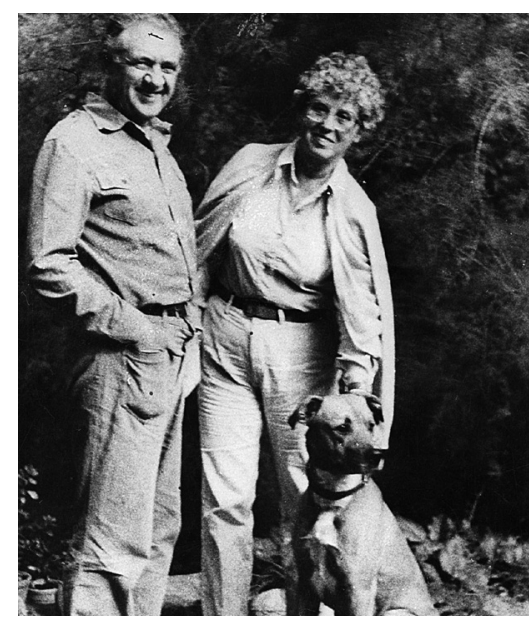

Fig. 1. Maria and Kazimierz Piechotka

Photo: K. Bałuk/Main Library; Warsaw University of Technology Faculty of Architecture at the Warsaw University of Technology in 1948. She began working with her husband in an author partnership in 1947 (Fig. 1).

Kazimierz Maciej Piechotka was born on 19 th $^{\text {November }} 1919$ in Warsaw; died on $6^{\text {th }}$ March 2010 in Warsaw. He attended school there and passed his secondary school final exam at Gen. J. Sowiński Secondary School in 1937. He was a scout. He started studying at the Faculty of Architecture at the Warsaw University of Technology in 1937. In his second year of studies, he became an assistant at the Department of Polish Architecture [ZAP]. During the war, he continued his studies at the Secret Faculty of Architecture at the Warsaw University of Technology and worked at ZAP. As a member of AK ["Home Army"], he worked in the Legalisation Studio "Gajewski". In the Uprising he fought in "Agaton" platoon of "Pięść" Battalion of "Radosław" Group. For his participation in the conspiracy and the Uprising, he was awarded the War Order of Virtuti Militari V Class, the Cross of Valour and the Bronze Cross of Merit with Swords. During the Uprising he married Maria Kazimiera Huber. Afterwards, he was a prisoner of war in Zeithain POW camp. After returning to Poland in May 1945, he took up a job in the Office for the Reconstruction of the Capital City [BOS], worked 
as an assistant at ZAP and continued his studies. He graduated from the Faculty of Architecture at the Warsaw University of Technology in 1946. Starting in 1947, he and his wife Maria cooperated as an author partnership. From 1950 to 1970 he was a chairman of the Residential Construction Section of SARP [Association of Polish Architects], and from 1956 to 1958 he was a vice-president for the creativity of the General Assembly of SARP.

They worked together since 1947. They are authors of the Bielany residential complex in Warsaw and the W70 and Wk70 systems of open building from large-size construction panels, as well as theoretical works on building construction, open typification and system design, and numerous publications on residential construction and the history of Jewish settlement, synagogue architecture and art in the former Polish-Lithuanian Commonwealth.

Awarded with: Knight's Cross of the Order of Polonia Restituta (1974), laureates of the Award of the City of Warsaw (1956); First Degree Award of the Chairman of the Committee for Urban Planning and Architecture (1956); Award of the Minister of Construction and Building Materials Industry (1967 and 1969); Second Degree State Award (1974); the status of Creator was granted to them by the Minister of Culture in 1981.

For their work on Jewish architecture, their efforts to portray the history of Poland as a multicultural, open and tolerant country, they were honoured with numerous awards: The Jan Karski and Pola Nireńska Award presented by YIVO in New York (2000); the Jan Zachwatowicz Award presented by the Polish Committee of The International Council on Monuments and Sites ICOMOS (2004). After her husband's death, Maria received the Irena Sendler Award of the Taube Foundation in 2016; the Gloria Artis Gold Medal awarded by the Minister of Culture and National Heritage in 2015; Honorary Membership of the Polish Institute for World Art Studies in 2015.

In 2018 she also received the Special Award of the Bielany Cultural Gala. She took great satisfaction from knowing that the residents of one of the Bielany housing estates designed by Maria and Kazimierz Piechotka had come up with an informal name for their complex, "Piechotkowo". She accepted all awards and distinctions as if they were shared with her husband.

In the introduction to the 2007 exhibition:

Maria and Maciej Piechotka: 70 years with architecture Maria wrote:

"We are among few of the last architects of the passing generation, born soon after the First World War, who began their architectural studies in Interwar Poland and continued them during the war, under the extraordinary conditions of the secret teaching, while serving in the Union of Armed Struggle at the same time (ZWZ AK). Our studies were interrupted by the Warsaw Uprising, followed by a detainment in a POW camp in Germany. Immediately after the war, we returned to Warsaw with the first possible transport. We immediately went onto finish the studies - starting our professional work at the same time. We kept this going intensively until we reached retirement age in 1980. Therefore, we can say that all of our design activity was bound up with the timeframe of PRL and was conditioned by it. It is a closed chapter, a period, also in our speciality of housing construction, which was condemned without any deeper analysis or discussion. It was summed up with two journalistic 
slogans: "first the repulsive socialist realism imposed by Moscow", then "hideous poverty - plattenbau apartment blocks, the cause of all evil", even where the buildings were typical, realised with the most traditional, artisanal methods.

Even though almost 20 years have passed since the collapse of the PRL, no one has given the problem an in-depth and comprehensive analysis. There has been no serious assessment of its undoubted shortcomings or possible advantages, especially in contrast with the present state of affairs.

Immediately after his return to Poland, Maciej took up a job at BOS and was an assistant at ZAP, where our design studio was located. Under the supervision of Professor J. Zachwatowicz, we prepared designs for the reconstruction of St. John's Cathedral, among other projects. In the first post-war years, the scope of our activities was very broad and varied. We still could work in many places at the same time, also on our own. We took advantage of it to a great extent. After a relatively short period of work on the reconstruction of historical monuments, Maciej's at the Office for the Reconstruction of the Capital City (BOS), and mine at the first Polish Studio for the Conservation of Cultural Property (PPKZ), we had already cooperated on numerous commissions. It was mainly research and scientific work on various subjects fort he Ministry of Reconstruction, and especially the Ministry of Culture, including: urban plans of small towns, designs of residential buildings, public buildings of various kinds and sizes - starting with projects of reconstruction and adaptation of two historic tenement houses at Długa Street and Podwale Street in Warsaw for the needs of the Music Industry Association, the office building of the Polish Music Society in Cracow including designs of interiors and furniture, the Cultural Centre in Zlotoryja and five small towns in Southern Poland to programme assumptions and concepts for the building of the Bank Gospodarstwa Krajowego in Gdańsk, the Orbis Hotel, the Archaeological Museum, the Central Cultural Centre in Warsaw (obviously not the one which was soon designed and built as a gift by Soviet comrades). We tested our skills in competitions. Among others, we won a distinction in the first competition announced in 1945 for the Warsaw Uprising Monument, $3^{\text {rd }}$ prize for the Central Department Store, $1^{\text {st }}$ prize in the competition for the design of the Ministry of Agriculture. (None of these was completed.) We began collecting material for a book on wooden synagogues.

At the turn of the 1940s /50s, the situation changed fundamentally. The free architectural design market ceased to exist. The only place for architects to work creatively was in the large state design offices. Maciej was accused by the party organisation at the Faculty of Architecture of propagating constructivism, functionalism, and Anglo-Saxon literature. Being recognised as an "ideologically alien element", he left the university. We became employees of the Miastoprojekt Stolica Północ. An order we received in 1951 for a complex design of project Bielany I determined that from then our primary focus was on housing, from an urban concept of a housing estate to an architectural detail of a building. It happened at the high time of the so-called socialist realism which started in 1948 with the National Party's Council of Architects and ended with the National Council of Architects organised by SARP in 1956. We were not affected by this as we were no longer involved in designing buildings 
significant for the regime. But we had to partly conform to the rules in our projects of development the main streets of Bielany: Aleja Zjednoczenia and Kasprowicza street. Otherwise, the projects would simply fail to be approved. We tried to use forms that were as simple and small in scale as possible, referring to the Warsaw classicism. The approving authorities found our solutions "modest but acceptable in Bielany, due to its peripheral location." (Figs. 2-4).

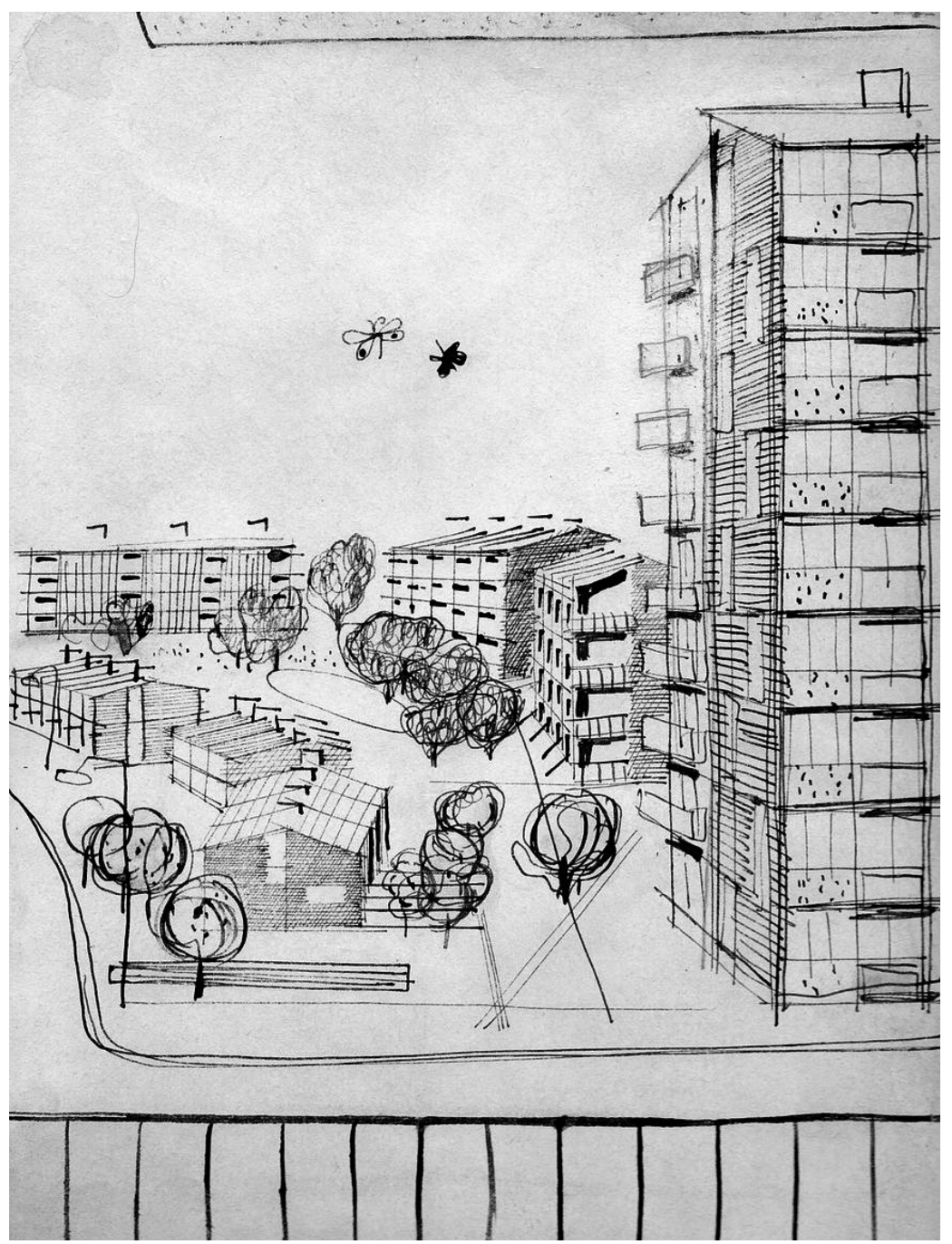

Fig. 2. Bielany II, picture K. Piechotka Source: from the family archive 


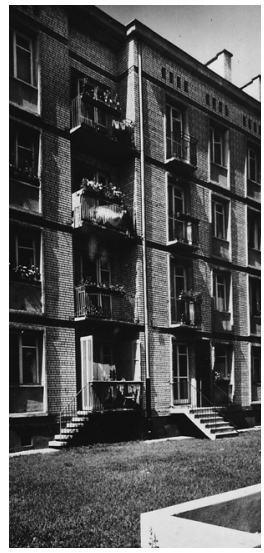

Photo: E. Kupiecki Bielany, 1958

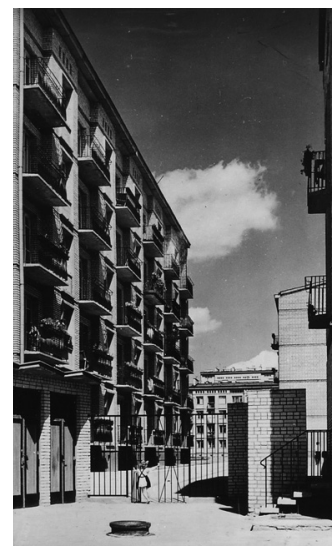

Photo: E. Kupiecki Bielany, 1958

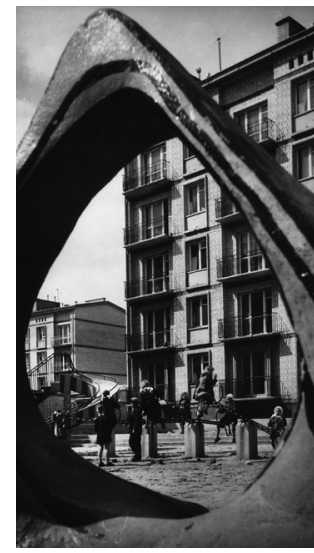

Photo: Z. Siemaszko Bielany, 1961

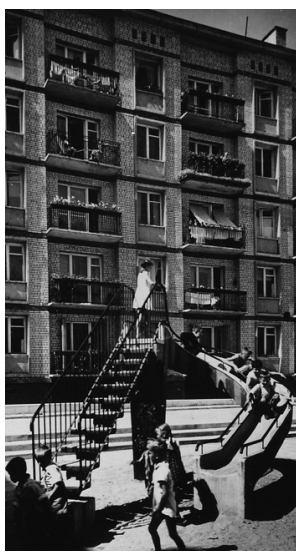

Photo: E. Kupiecki Mid-block interior

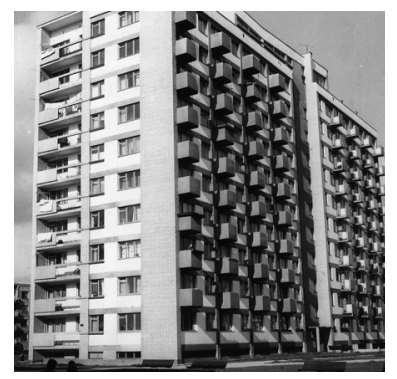

Photo: CAF. Mister Warszawy 1965, House at Magiera street

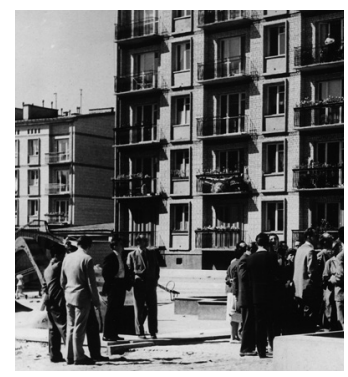

Photo: Wł. Piotrowski Bielany I

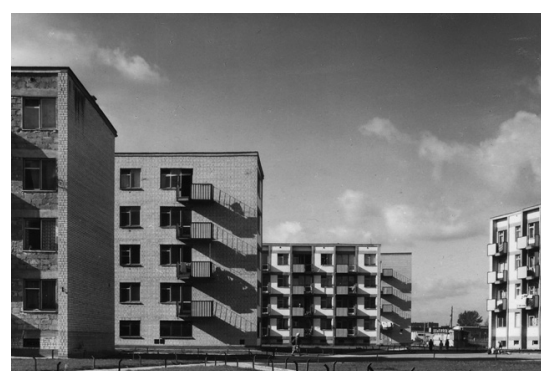

Photo: A. Zborski, Bielany III, 1962

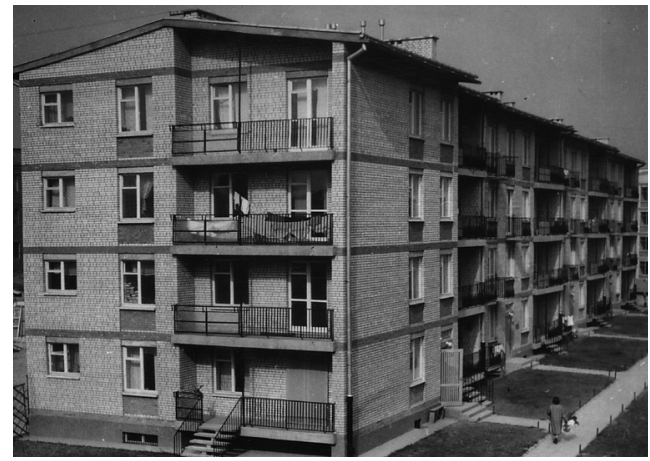

Photo: T. Rolke, Bielany III, 1959

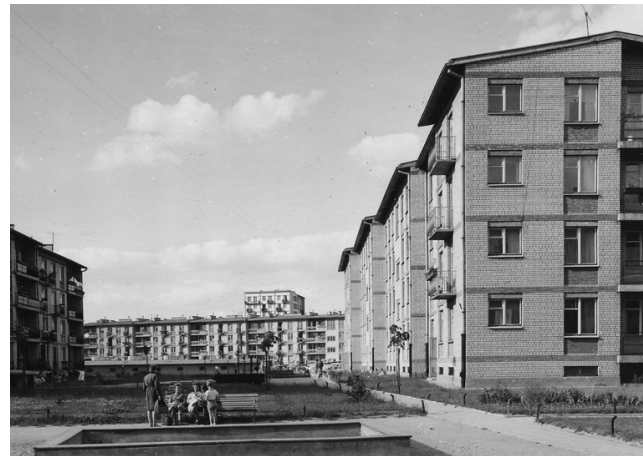

Photo: AN, Bielany II

Fig. 3. Examples of the designs implemented by the MiK Piechotka Company in the Warsaw district of Bielany 


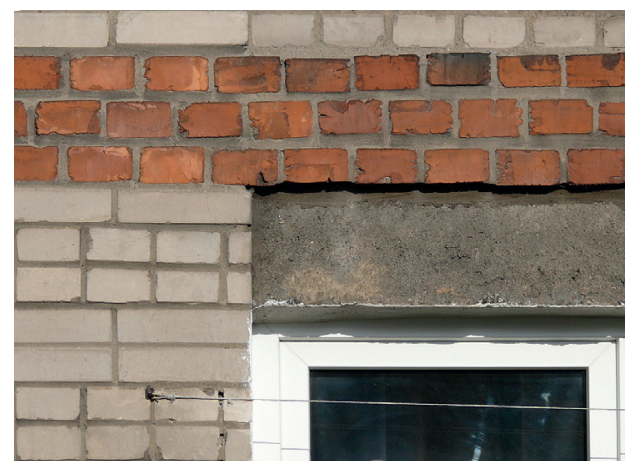

Bielany II, S. Żeromskiego 4 street fragment of the original facade

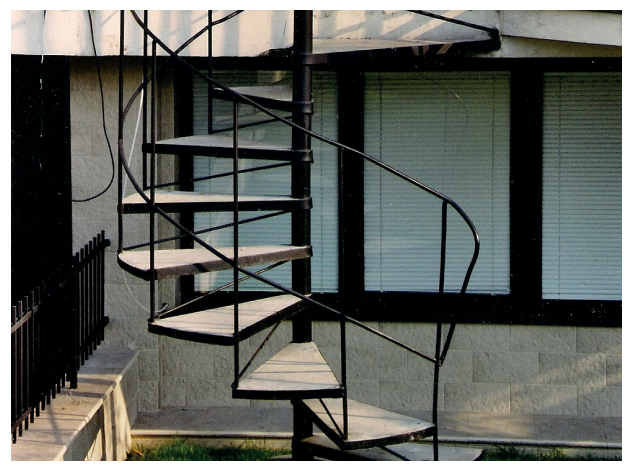

Bielany II, Sentymentalna street (presently M. Pawlikowskiej-Jasnorzewskiej)

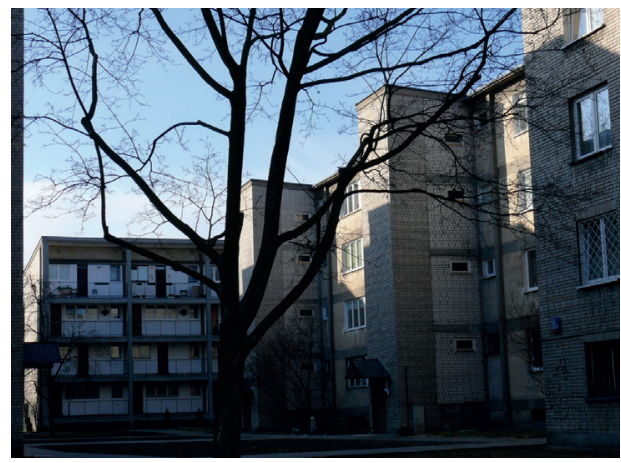

Bielany III, A. Magiera street

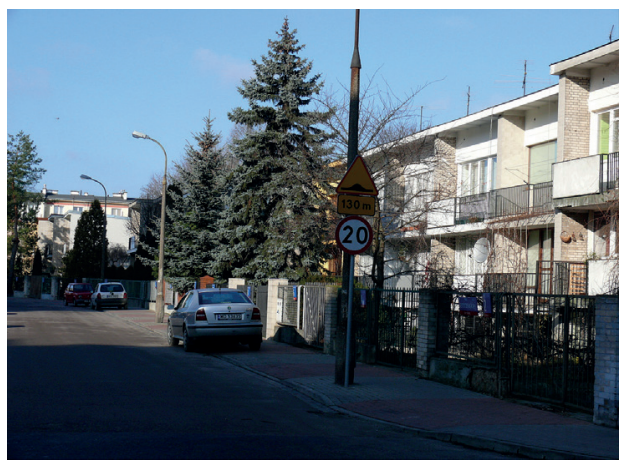

Bielany II, Sentymentalna street (presently M. Pawlikowskiej Jasnorzewskiej)

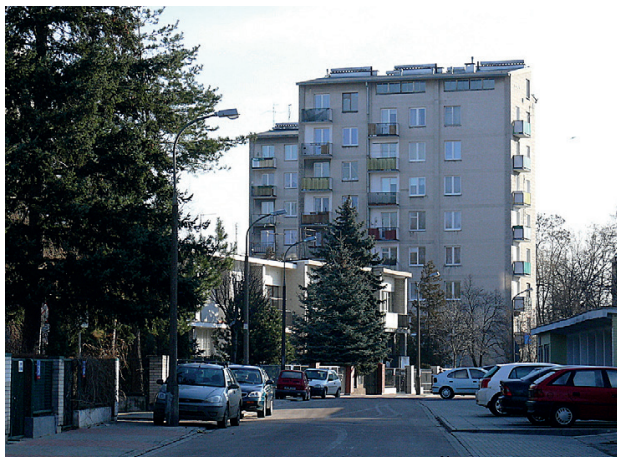

Bielany II, Sentymentalna street (presently M. Pawlikowskiej-Jasnorzewskiej)

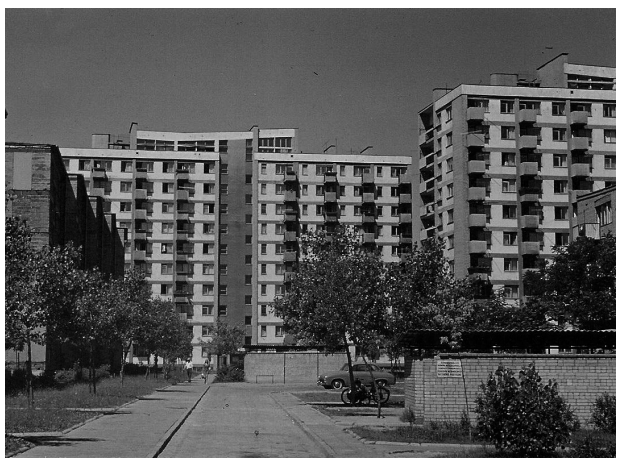

Bielany III, A. Magiera street

Fig. 4. Examples of the designs implemented by the MiK Piechotka Company in the Warsaw district of Bielany 
Our escape from socialist realism was in designing exhibitions and decorations for international conferences, where the principles of socialist realism did not apply. Alongside designing the Bielany district, we took part in preparing large exhibitions, such as the Industry of the People's Republic of China at Jabłkowscy Brothers or Renaissance and Enlightenment at the National Museum. We designed the interior decoration of the House of the Polish Word for the Second World Peace Congress and the hall of the Warsaw University of Technology for the First Congress of Polish Science, the street decorations of Nowy Świat and Krakowskie Przedmieście for the famous World Festival of Youth and Students in 1955. Despite Maciej's "voluntary" resignation from ZAP in 1952, we continued our work on the book on wooden synagogues. It was published as the first post-war ZAP publication in 1957, and in 1959 it was published in English translation.

Between 1955 and 1957 we managed to build a group of buildings on Skalbmierska Street. Among other materials, we used silicate bricks for the facades. They were already finished when the Warsaw authorities decided to show the PZPR Politburo, headed by the newly elected First Secretary Władysław Gomułka, what and how was being built in the capital. They also came to Skalbmierska Street and as architects, we had to be present on-site to provide explanations just in case. And then we heard Prime Minister J. Cyrankiewicz say to Gomułka: "Comrade, look, Piechotkas used fortochkas and socialism has not collapsed". (At that time, the entire building industry, regardless of the size of the room, was obliged to use one type of window - C2, double-leaf without a fortochka). The next day we received a letter from the Prime Minister's Office informing us that we had been issued passports and granted a two-week grant to travel to Paris to familiarise ourselves with the residential housing there. The project at Skalbmierska Street was recognised as the first breach in socialist realism in the construction industry. We received the award of the Capital City of Warsaw and the first-degree prize of the Chairman of the Committee on Urban Planning and Architecture.

We became fully involved in the broad field of residential architecture after the revolts in October 1957. It was when the Section of Residential Building of SARP became very active. It had existed since the beginning of the 1950s and Maciej was its chairman from the beginning till the 1970s. It consisted mainly of architects - Warsaw housing experts. We were all, and later many of our younger colleagues from all over Poland, very professionally, socially and emotionally involved in what and how we were designing. We believed that it was our duty to create the best possible living conditions for all the residents in the then very difficult and harsh technical and material conditions, economic and normative limitations. We were striving to improve the housing standards, to create common recreation and leisure areas, to implement accompanying projects and to ensure proper placement of children's facilities, etc.

Between 1958 and 1964 we designed four more housing estates in Bielany. They were designed in stages, first was Bielany II - the so-called "serek Bielański", then the housing estates in Magiera Street, Słodowiec, and the last one - the "Osiedle Zjednoczenia". Like other housing projects built at that time they were relatively small, each for about 10,000 inhabitants. The time of large housing estates - districts designed as a whole from one projection did not yet arrive. Our projects were following the guidelines of the Warsaw General Plan but 
keeping in mind the existing urban structure. We preserved the radial street pattern and the scale of development, which had been designed before the war. We tried to give each estate a different, distinctive layout and architectural expression but open to the common public space. Only for "serek Bielański" and the housing estates at Magiera did we manage to design both urban planning with buildings. When working on Słodowiec and Osiedle Zjednoczenia we had to choose residential buildings from the Warsaw catalogue.

In 1965 a decision was made to allocate considerable funds for the creation of a network of large-panel element factories across the country. The factories were supposed to be equipped with high-capacity production equipment imported from abroad, including the dollar zone, which would ensure a much better quality of products than previously. We feared that once again these machines would have a limited product range, that the whole of Poland would be covered, with identical large-panel "typicals." This had to be prevented at all costs. A nationwide contest was organised for the project of a building system based on large-size concrete panels, which, considering the conditions of industrial production, transport and simplicity of assembly, would at the same time allow for as much freedom as possible to shape functions and architectural forms of buildings. After the first phase of the contest, in which 40 teams from all over Poland took part, it was decided to adopt the so-called "Szczecin System" for the first few factories and equip them with machines purchased in the USSR. The second phase of the contest resulted in the selection of our "Open System of Construction from Large Elements W 70" for implementation.

The essence of the W 70 system was to introduce series of basic, architecturally neutral building elements, manufactured in precisely constructed forms - walls, ceilings, staircases, roof slabs, with measurements compliant with the international standards of modular coordination and the manner of their assembly, i.e. system joints, allowing for great freedom in shaping the function and body of buildings. The way of using the system and the architectural detail of a building depended on the needs and willingness, skills and creativity of authors and designers of specific projects.

Factories of the W 70 or Wk 70 system elements were opened in the whole country. Under the original assumption, their mutations were created, designed by the architects of specific projects, such as Tychy, Nowe Miasto Zamość or Warsaw Ursynów. The only project we designed that was built with the system is a small complex of single-family houses on the outskirts of Ursynów. The conceptual designs of the Nowo Bema residential complex in Warsaw and the Orbis hotels in Gdynia and Łódź remained on paper.

Expanding on the principles adopted in the W 70/Wk 70 system, we designed an open ECA system for Algeria in 1977-1979. We took into account the architectural traditions, utility needs, climatic conditions and seismic risks of the region.

It goes without saying that we did not work alone during all this time. We had a large multi-discipline studio with personnel changing over time. It is impossible to mention everyone - there were so many of them. We thank them sincerely. At the same time, both of us developed the "Concept, Basis and Work Programme" for the integration of the IS general construction in 1973-1974. It was approved by the Ministry of Construction and Building Materials Industry in 1976. 
In 1980 it turned out that being 60 years old, whether I wanted to or not, I had to retire in the middle of working on the IS. Maciej exercised his veteran's rights and left a few months later. The last task we managed to complete before definitely leaving the office was the "IS General Principles". It was published in book form by the COBPBO [Central Research and Design Centre for General Construction] in 1984. But things changed shortly afterwards and it became completely irrelevant.

In 1984, we received a proposal from the Institute of Art of the Polish Academy of Sciences to participate in the government programme "Jewish Architecture and Art". It was a return to this subject after a thirty-year break since the publication of our book "Wooden Synagogues". This was the beginning of a new, twenty-four-year stage in our lives, which resulted in a publication of our three new books on synagogue architecture and art portrayed in view of the history of Jewish settlement in the territories of the former Polish-Lithuanian Commonwealth (Figs. 5 and 6):

- Bramy nieba. Bóżnice drewniane na ziemiach dawnej Rzeczypospolitej, Wydawnictwo Krupski i S-ka, Warszawa 1996.

- English edition: Heaven's Gates. Wooden synagogues in the territories of the former Polish-Lithuanian Commonwealth, publishing house Krupski i S-ka, Warsaw 2004.

- Bramy nieba. Bóżnice murowane na ziemiach dawnej Rzeczypospolitej (Heaven's Gates. Masonry synagogues in the territories of the former Polish-Lithuanian Commonwealth), Wydawnictwo Krupski i S-ka, Warszawa 1999.

- Oppidum Judaeorum: Żydzi w przestrzeni miejskiej dawnej Rzeczypospolitej (Oppidum Judaeorum: Jews in cities of the former Polish-Lithuanian Commonwealth), Wydawnictwo Krupski i S-ka, Warszawa 2004.

- The fourth book, Krajobraz z menora (Landscape with a Menorah), is due to be published later this month and will mark the end of our 70-year relationship with architecture."

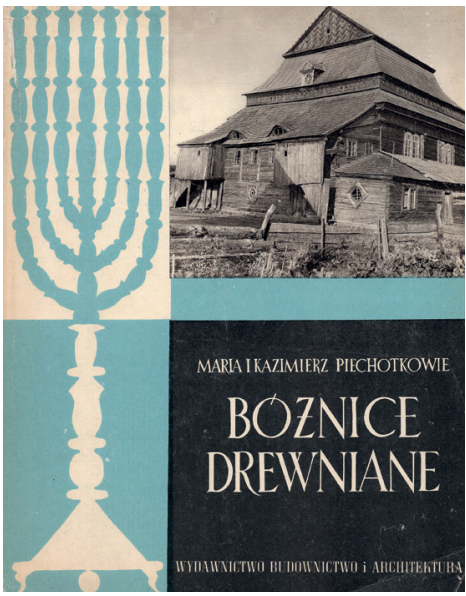

Fig. 5. Bóżnice Drewniane (Wooden synagogue), cover

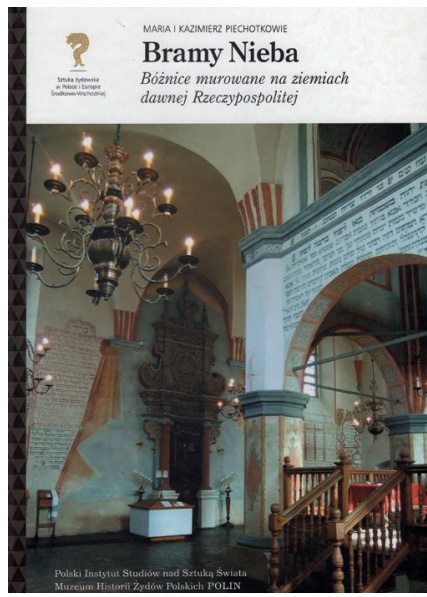

Fig. 6. Bramy Nieba (Heaven's Gates), cover Source: from the family archive

Source: from the family archive 
They continued to work on Jewish architecture and urban planning after the exhibition. After the death of her husband in 2010, Maria continued the work she had started with her husband. Among other things, she prepared an English edition of the book Landscape with Menorah in collaboration with the Salix Alba publishing house in 2015.

An expanded version of all three books on Jewish architecture and settlement was prepared for the Polish Institute of World Art Studies. As a result of cooperation between PIBnSS (Polish Institute of World Art Studies) and POLIN Museum, the following books were published in Polish and English as part of the series "Jewish Art in Poland and Central and Eastern Europe": Heaven's Gates. Wooden synagogues in the territories of the former Polish-Lithuanian Commonwealth, Warsaw 2015; Heaven's Gates. Masonry synagogues in the territories of the former Polish-Lithuanian Commonwealth, Warsaw 2017; and prepared for publishing Oppidum Judaeorum: Jews in cities of the former Polish-Lithuanian Commonwealth.

\footnotetext{
Michat Piechotka, born in 1948 in Cracow, M.Sc. in architecture, diploma from the Faculty of Architecture, Warsaw University of Technology. Employee of design offices and studios in Warsaw and Algeria. Author and co-author of a number of studies, designs, architectural realisations and exhibitions. In 1989-2005 employee of architectural and construction administration offices. Member of SARP (Society of Polish Architects).

Michał Piechotka, ur. 1948 r. w Krakowie, mgr inż. arch., dyplom Wydziału Architektury Politechniki Warszawskiej. Pracownik biur i pracowni projektowych w Warszawie i Algierii. Autor i współautor szeregu opracowań studyjnych, projektowych, realizacji architektury i wystaw. W latach 1989-2005 pracownik urzędów administracji architektoniczno-budowlanej. Członek SARP (Stowarzyszenie Architektów Polskich).
}

Maciej Piechotka, born in 1952 in Warsaw, M.Sc. in architecture, diploma from the Faculty of Architecture, Warsaw University of Technology. Employee of design offices and studios, author of a number of projects. From 1981 to 1986 lecturer at the University of Nigeria, Department of Architecture. Member of SARP (Society of Polish Architects) and MOIA (Mazovian Regional Chamber of Architects).

Maciej Piechotka, ur. 1952 r. w Warszawie, mgr inż. arch., dyplom Wydziału Architektury Politechniki Warszawskiej. Pracownik biur i pracowni projektowych, autor szeregu realizacji. W latach 1981-1986 wykładowca na Uniwersytecie Nigieryjskm, na Wydziale Architektury. Członek SARP (Stowarzyszenie Architektów Polskich) i MOIA (Mazowiecka Okręgowa lzba Architektów). 